\title{
高血圧性脳出血の血腫吸引術後の症状および 脳血流量の変化について
}

\author{
雄山 博文, 丹羽 政宏, 木田 義久 \\ 田中 孝幸, 前沢＼cjkstart聡，小林 達也
}

\section{The Change of Neurological Symptom and Cerebral Blood Flow after Aspiration of Hypertensive Cerebral Hemorrhage in the Chronic Phase}

Hirofumi Oyama, M.D., Masahiro Niwa, Yoshihisa KIDA, M.D.,

Takayuki TanaKa, M.D., Satoshi Maezawa, and Tatsuya Kobayashi, M.D.

Department of Neurosurgery, Komaki City Hospital, Komaki, Japan

\begin{abstract}
Summary : We analyze the change of neurological symptoms and cerebral blood flow (CBF) after aspiration of hypertensive cerebral hemorrhage in the chronic phase in 9 cases. In 7 cases, the paresis improved moderately 4.7 days after the operation. In 5 cases, aphasia improved markedly 4 days after the operation, and the patients became able to converse. However, CBF did not change so much even after the aspiration. The pre- and post-operative hemispheric $\mathrm{CBF}$ of the affected side were $38.4,38.3 \mathrm{~m} / / 100 \mathrm{~g} / \mathrm{min}$ in the basal ganglia level and $38.5,34.2 \mathrm{~m} / / 100 \mathrm{~g} / \mathrm{min}$ in the lateral ventricular level. Those of the non-affected side were $48.9,50.1 \mathrm{~m} / / 100 \mathrm{~g} / \mathrm{min}$ in the basal ganglia level and $47.8,45.1 \mathrm{ml} / 100 \mathrm{~g} / \mathrm{min}$ in the lateral ventricular level. This gap between the change of neurological symptom and that of $\mathrm{CBF}$ was sigificant.
\end{abstract}

Key words :

- aphasia

- paresis

- $\mathrm{CBF}$

- aspiration

- cerebral hemorrhage
はじめに

脳出血において脳血流がびまん性に減少することはよく 知られており，その原因として，頭蓋内圧六進による脳灌 流圧低下，および脳の代謝，機能の低下などが関与してい ると考えられている．血腫周囲組織にかかる圧力を減少さ せ，脳灌流圧を増加させることを目的として，血腫吸引術 が行われているが, その効果については議論の分かれると ころである．我々は 9 例において血腫吸引術前後の症状の 変化を観察し，併せ Xenon-enhanced CT 法による CBF (cerebral blood flow) 測定も行ったので報告する.
対象および方法

対象は高血圧性脳出血の慢性期において穿頭術による血 腫吸引術を行い，その前後に脳血流を測定しえた 9 例であ る (Table 1). 男 5 例，女 4 例で，平均年齢は 57.6 歳であ った. 血腫の部位は被款出血 5 例, 皮質下出血 4 例であり, 右側 3 例, 左側 6 例であった. 手術は発症後12〜27日 (平 均 20.4 日) に行い, 吸引された血腫量は $11 \sim 40 \mathrm{ml}$ (平均 $26.2 \mathrm{ml}$ ) であった. 術後運動麻痺, 失語の改善を観察し, 手術よりその改善が見られた時までの日数を計測した。

手術前の $\mathrm{CBF}$ 測定は発症後 3〜24日 (平均12.4日)に, 
Table 1 Summary of cases

The classification of paresis. 5: normal, 4: good, 3: fair, 2: poor, 1: trace

\begin{tabular}{|c|c|c|c|c|c|c|c|c|c|c|c|c|}
\hline \multirow{2}{*}{\multicolumn{3}{|c|}{ Case }} & \multirow{2}{*}{\multicolumn{2}{|c|}{ Hematoma }} & \multirow{2}{*}{\multicolumn{2}{|c|}{ Operation }} & \multicolumn{6}{|c|}{ Paresis } \\
\hline & & & & & & & \multicolumn{3}{|c|}{ upper $\operatorname{limb}$} & \multicolumn{3}{|c|}{ lower limb } \\
\hline No. & age & gender & side & location & $\begin{array}{l}\text { time } \\
\text { (days after } \\
\text { the onset) }\end{array}$ & $\begin{array}{l}\text { aspirated } \\
\text { volume } \\
(\mathrm{m} l)\end{array}$ & preope & postope & $\begin{array}{l}\text { time to the } \\
\text { improvement } \\
\text { (days) }\end{array}$ & preope & postope & $\begin{array}{l}\text { time to the } \\
\text { improvement } \\
\text { (days) }\end{array}$ \\
\hline 1 & 50 & $\mathrm{~F}$ & lt & putamen & 27 & 30 & 1 & 1 & & 1 & 1 & \\
\hline 2 & 55 & $\mathrm{M}$ & lt & putamen & 16 & 36 & 1 & 1 & & 1 & 2 & 1 \\
\hline 3 & 61 & M & lt & putamen & 20 & 11 & 1 & 1 & & 1 & 2 & 3 \\
\hline 4 & 49 & $\mathrm{M}$ & $\mathrm{rt}$ & putamen & 24 & 40 & 1 & 1 & & 1 & 2 & 4 \\
\hline 5 & 72 & $\mathrm{~F}$ & $\mathrm{rt}$ & putamen & 19 & 20 & 1 & 1 & & 1 & 2 & 6 \\
\hline 6 & 56 & $\mathrm{M}$ & lt & temporal & 25 & 19 & 2 & 3 & 12 & 2 & 3 & 12 \\
\hline 7 & 55 & $\mathrm{~F}$ & lt & temporal & 18 & 35 & 5 & 5 & & 5 & 5 & \\
\hline 8 & 57 & $\mathrm{M}$ & $\mathrm{rt}$ & temporal & 23 & 25 & 1 & 3 & 2 & 4 & 4 & \\
\hline 9 & 63 & $\mathrm{~F}$ & lt & parietal & 12 & 20 & 3 & 4 & 5 & 3 & 4 & 5 \\
\hline
\end{tabular}
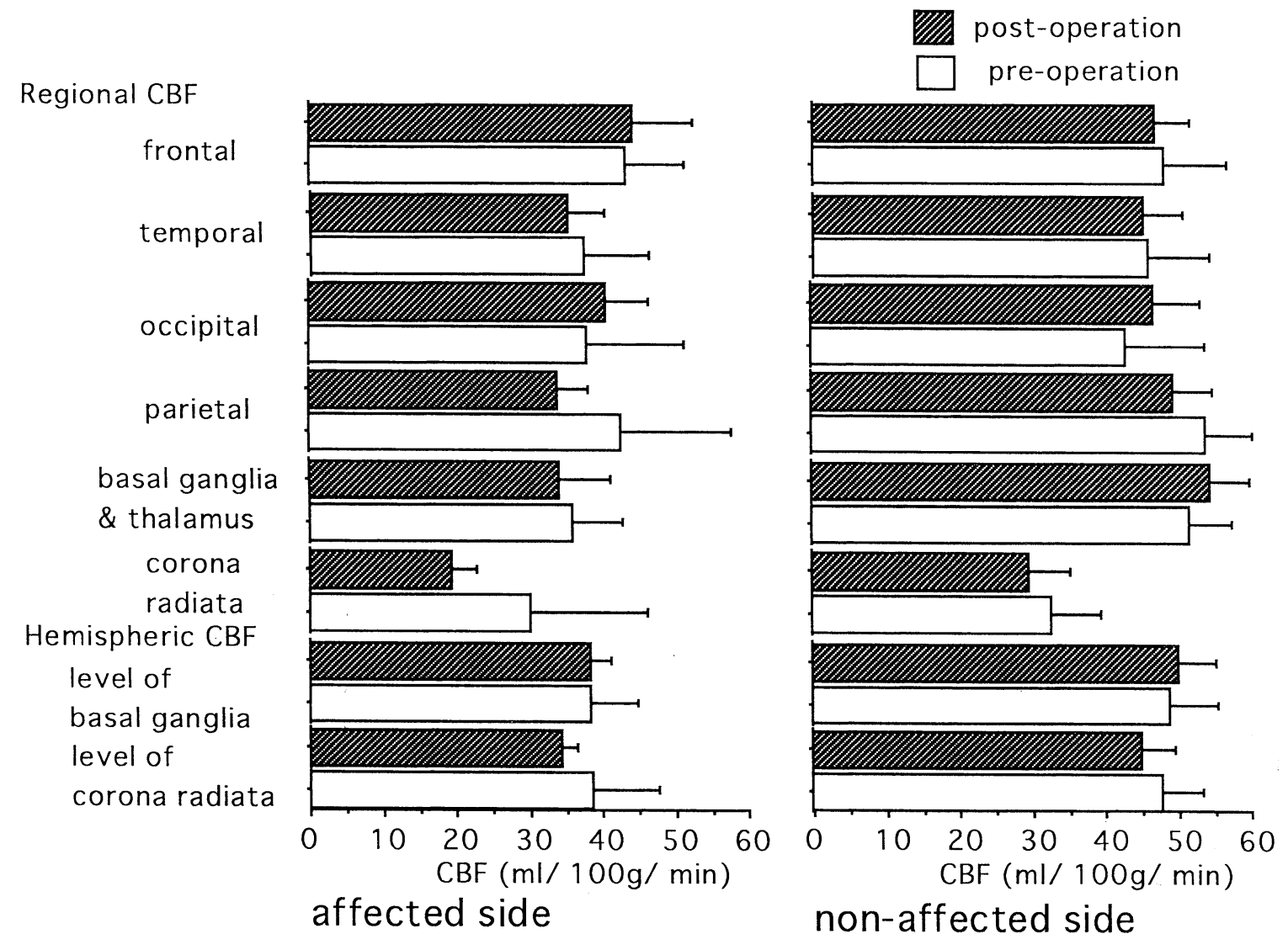

Fig. 1 Regional and hemispheric $\mathrm{CBF}$ before and after the operation. CBF did not change significantly after the operation. Bar shows the standard deviation. 


\begin{tabular}{|c|c|c|c|c|c|}
\hline \multicolumn{6}{|c|}{ Aphasia } \\
\hline \multicolumn{3}{|c|}{ motor } & \multicolumn{3}{|c|}{ sensory } \\
\hline preope & postope & $\begin{array}{l}\text { time to the } \\
\text { improvement } \\
\text { (days) }\end{array}$ & preope & postope & $\begin{array}{l}\text { time to the } \\
\text { improvement } \\
\text { (days) }\end{array}$ \\
\hline$(++)$ & $(+)$ & 2 & $(++)$ & $(+)$ & 2 \\
\hline$(++)$ & $(+)$ & 4 & $(-)$ & $(-)$ & \\
\hline$(-)$ & $(-)$ & & $(++)$ & $(+)$ & 5 \\
\hline$(-)$ & $(-)$ & & $(-)$ & $(-)$ & \\
\hline$(-)$ & $(-)$ & & $(-)$ & $(-)$ & \\
\hline$(-)$ & $(-)$ & & $(++)$ & $(+)$ & 3 \\
\hline$(-)$ & $(-)$ & & $(++)$ & $(+)$ & 6 \\
\hline$(-)$ & $(-)$ & & $(-)$ & $(-)$ & \\
\hline$(-)$ & $(-)$ & & $(-)$ & $(-)$ & \\
\hline
\end{tabular}

手術後の測定は発症後 21〜65 日 (平均 37.4日)に行った. Xenon-enhanced CT 法 (30\% Xenon gas, 3 分吸入, 5 分 排出)により測定し, 各脳葉, 大脳基底核および視床, 放 線冠での局所血流量，および大脳基底核，放線冠レベルで の半球血流量を計算した. Xenon gas 吸入装置は AZ-721 (Anzai Sogyo Co., LTD, Tokyo, Japan), CT scanner は Somatom plus (Siemens, Erlangen, Germany)を用いた。 手術前後の血流量の差を paired $t$-testにて検討し, $p \leqq 0.05$ 有意とした.

\section{結果}

9 例中 7 例において, 手術 1〜12日 (平均 4.7 日) 後に運 動麻痺の改善を認めた (Table 1). 改善の程度は 5 段階の うちの 1 段階のみに留まるものがほとんどで比較的軽度で あった。 また 9 例中 5 例において, 手術 2〜6日 (平均 4 日)後に失語の改善を認めた. 失語の改善はかなり著しく, 日常会話ができるようになるほどであった。

血腫側の大脳基底核および放線冠レベルでの半球血流量 は 38.4 および $38.5 \mathrm{~m} / / 100 \mathrm{~g} / \mathrm{min}$, 非血腫側のそれは 48.9 および $47.8 \mathrm{~m} l / 100 \mathrm{~g} / \mathrm{min}$ であり, 血腫側でのかなりの減 少が認められた Fig. 1). 血腫吸引術後の, 血腫側の大脳 基底核および放線冠レベルでの半球血流量は 38.3 および $24.2 \mathrm{~m} l / 100 \mathrm{~g} / \mathrm{min}$, 非血腫側のそれは 50.1 および 45.1 $\mathrm{m} l / 100 \mathrm{~g} / \mathrm{min}$ であり, 明らかな改善を認めず, 放線冠レ ベルにおいてはむしろ減少している傾向がみられた。いず れの部位でも手術前後の血流量の変化に有意差はみられな かった。

\section{考察}

一般に血腫が内包にかかっていない限り血腫吸引術によ り運動麻瘏の改善はありえ, また意識障害, 失語もかなり 改善すると報告されている ${ }^{2) 3)}$. 我々の症例でも, 術後比 較的早期に症状の改善を認めたことより, 自然回復のみで なく血腫吸引術の効果があったことが推測される．失語に 関してはかなりの改善を認めたが，運動麻痺の改善は 5 段 階中せいぜい 1 ～ 2 段階と軽度であった.このように失語 症の改善が比較的良好であったことは，手術適応を考える 上で参考になると思われる.

血腫吸引術後の CBF の変化については, 改善を認めた としてもかなり緩徐で，数力月を要するいう報告が多い5) 6)8）. 更に，被殼出血，視床出血よりも皮質下出血のほう が術後の CBF の改善が良いことも知られている6). 我々 の例では発症約 1 力月後に術後の測定が行われたが, 被款 出血, 皮質下出血とも CBF に明らかな改善を認めず, む しろ部位により低下していることもあった．運動麻痺もし くは失語の改善を認めたにもかかわらず, CBF に明らか な改善を認めていないことは, 誠に興味深い. その理由と して, 1 ) 発症後, 脳の機能低下と平行して CBF は減少 していくが，血腫吸引はその長期的な CBF 減少を多少抑 えるに留まり，それを明らかに増加させるまでには至らな かった ${ }^{7)}$ 8) 2 ) 急性期においては脳圧が上昇し脳灌流圧が 減少するといわれているが，慢性期では血腫がその周囲に 及ぼす圧力はさほど高くはなく, 術後目立った血流の増加 をきたすほどではなかっだ)。等が考えられる.

このように考えると, 手術時期に関してはまだまだ議論 の余地があると思われる. 血腫周囲組織の二次的変化の発 生, 進展は, 発症後 6 時間目より始まり，4 日目にピーク となるといわれている1). 我々の例では血腫の溶解するの を待って発症後 12〜27日目に手術を行ったが, この二次 的変化の進展を更に抑えるには，手術時期をもう少し早め た方がよいのかもしれない。

$$
\text { まと め }
$$

高血圧性脳出血の慢性期における血腫吸引術を行い, そ の前後に脳血流を測定しえた 9 例について, 症状, $\mathrm{CBF}$ (cerebral blood flow)の変化を検討した. 9 例中 7 例にお いて手術後平均 4.7 日後に運動麻痺の改善を認めたが, 改 善の程度は比較的軽度であった。 また 9 例中 5 例において 平均 4 日後に失語の改善を認めたが, 失語の改善はかなり 著しく日常会話ができるようになるほどであった。しかし 血腫吸引術後 $\mathrm{CBF}$ は明らかな改善を認めなかった. $\mathrm{CBF}$ に明らかな改善を認めていないにもかかわらず症状の改善 を認めたことは，誠に興味深いことと思われた。 


\section{文献}

1）久門良明，榊 三郎：定位的血腫吸引術. 日本臨床 51: 77-84, 1993

2) Kuroda K, Kitakami A, Tsuiki K, et al: Motor function in putaminal hemorrhage with compression of the posterior limb of the internal capsule and treatment policy. In: Brain Hemorrhage '95 vol. 1 (Proceeding of the 1st Annual Meeting of Intracerebral Hemorrhage), 1995, pp 195-203

3) Tanikawa $\mathrm{T}$, Iseki $\mathrm{H}$, Taira $\mathrm{T}$, et al: Immediate effects of stereotactic aspiration of intracerebral hematoma on neurological disorders. In: Brain Hemorrhage '95 vol. 1 (Proceeding of the 1st Annual Meeting of Intracerebral Hemorrhage), 1995, pp 117-126

4) Tsurutani $T$, Orita $T$, Kitahara $T$ : Intracranial pressure fol- lowing stereotactic aspiration of hypertensive hematoma. In: Brain Hemorrhage '95 vol. 1 (Proceeding of the 1st Annual Meeting of Intracerebral Hemorrhage), 1995, pp $87-91$

5）上田幹也，井上慶俊，林 征志，ほか：SPECTによる被凯 出血に対する外科的治療の評価. CT 研究 14: 533-543, 1992

6) Watanabe H, Yoshida K, Nakamura S: Sequential cerebral blood flow changes in patients with surgically-treated hypertensive intracerebral hematoma. In: Brain Hemorrhage '95 vol. 1 (Proceeding of the 1st Annual Meeting of Intracerebral Hemorrhage), 1995, pp 79-85

7）山下哲男，柏木史郎，中野茂樹：高血圧性脳出血. キセノ ンCT一入門編一，にゅー万人社，東京，1991，pp 59-60

8）吉永真也：高血圧性被㐖出血の脳循環. 脳神経外科 22 : 223-229, 1994 